\title{
Investigating multilingual contexts in the Nigerian advertising space: A domain of intellectual stimulation
}

\begin{abstract}
This study examined advertising, exhibiting multilingual structures to reach the Nigerian audience. Halliday's mood system and morphological processes served as the theoretical configurations for analyzing textual elements of advertisements. These contextual terminologies permitted quantitative and qualitative approaches to thrive in order to culminate the investigation. Thus, the analysis showed political motifs, religious spheres, royal domains, musical settings, and friendship environment, as the fascinating panaceas to motivate readers. English, Yorùbá, and Hausa languages were functional facilities to mesmerize consumers. However, the advertisements displayed textual interruptions: $F E$ BUHARI, FELABRATION, OBIdiently, and ATIKUlating, being strong prerequisites in persuasive designs. Creativity indicates the logically-minded behavior of publicists in blending grammatical structures of different languages together, yielding a unified whole, generating novel semantic values for regurgitation. It seems indisputable that such textual constructs have the capability to influence lexicographers, increase word-stock(s) of languages, and projecting the advertising industry as possessing cerebral proficiencies in linguistics' advancement.
\end{abstract}

Keywords: advertising, intellectualism, mood system; morphology, multilingual context.

\section{Introduction}

It is neither contradictory nor a super-imposed statement if one considers advertisers as sages or perhaps, linguistic wizards. This is because advertising represents a construct that is based on purpose in order to gratify a particular need. The textual appearance of advertising, among other traits, is informed by the following elements: the nature and participation of the target audience, the socio-cultural domain of the target audience, the competing business environment of the product, and the desire of the advertising mechanics to operate in distinction (Bogart 1995; Dalamu 2018a). These are some of the

1 Address for correspondence: Department of English and Literary Studies, Anchor University, AyoboIpaja, Lagos State, Nigeria. E-mail: tdalamu@aul.edu.ng 
reasons that project advertising exploits-cum-textual matters as a motivation of intellectualism. The erratic behaviors of the audience from diverse socio-cultural settings appear to influence advertising practitioners to the kind of advertisements (henceforth: ads) that are propagated. This factor regulates to contribute to the success recorded in advertising (Ang 1991; Myers 1994). This inevitable contextual variable propels the experts in the field to be liberal in shaping advertising texts. So, when advertisers maneuver textual elements in rule governed and "deviant" ways, the persuasive goals to be achieved compel the experts to behave in somewhat impulsive manners (Dalamu 2019b). Ads are produced not only for the consumption of the consumers but also for the target audience to submit to the message and content that advertisers proliferate.

On the one hand, looking at advertising campaigns from an external perspective, any ad takes into consideration the involvement of the audience. The characterization of the audience participation in advertising, in Greenwald \& Leavit's (1984) standpoint, exhibits four distinctions. These are pre-attention, focal attention, comprehension and elaboration which are revealed as personal connections. In the quest of giving reflection to the audience, the cultural atmosphere becomes crucial and a contributory factor (Cook 1992; Gieszinger 2001; Goddard 2011). As stated earlier, an important indicator that signals the direction of the advertising text is the immediate environment on which the business operates. It is common knowledge that there is no business situation with a monopolistic power. Goods and services, in the current global market, face several challenges (Harris \& Seldon 1962). That status facilitates the nature of craft that advertising is made of, most especially, in relation to textual devices.

On the other hand, there is an internal factor of advertising motivation. An advertising professional perceives his/her discipline as distinct scenery with the goal of producing ads that are not only creative but also appealing. This intrinsic factor inspires the expert to do more than the colleagues and counterparts, competing in the same market. Because of that, a practitioner begins to pursue intellectual ambition, giving credence to a search for something novel. The individual, in Dalamu's (2020) manifestation, attempts to construct texts in ways that satisfy a purpose. Thus, in creativity, new words are formed as the expert manipulates linguistic devices by considering the framework, in which the ad will eventually circulate. The long term effect of an expert's production on dexterity of advertising texts might encourage a consistent patronage of recipients as well as clients. As a result of the external and internal motifs advertising moulds and multiplies texts into a series of contextual figures - hence, the argument of this paper.

Some linguistic paradigms of Nigeria, being a multilingual, and ipso facto, a multicultural state, have been addressed in Emenanjo (1990). Most of the contributions of the essayists, in Emenanjo (1990), are still relevant in the current discourses of multilingualism in Nigeria. This is because scholars still construct their arguments from the contributions in the edited book (Dalamu 2017a). Scholars have also discussed issues of 
language pluralism (Kaplan \& Baldauf Jr. 2007), bilingualism in terms of code-switching and code-mixing (Igboanusi 2001), and marginalization regarding minority languages (Awobuluyi 2010; Ozo-mekuri 2010). Other studies predicate on language legislation and planning (Ojelade \& Ezenandu 2010), and the teaching-cum-learning of languages in Nigeria, inclusive of Pidgin (Akinnaso 2015). The central communicative domain of this article is to investigate ads from their multilingual contexts, though distinctive, adding spices to earlier contributions. In spite of the fact that there are analyses of advertising contents in various socio-cultural settings as persuasive tools in marketing dynamics (De Pelsmacker et al. 2002; Malaviya 2007; Alt et al. 2009; Bakshy et al. 2012), the analyst is not aware of studies in the direction of diversified cultural horizons, especially, in the Nigerian environment. However, this study has described how ads' mechanisms, in a specific socio-cultural context - Nigerian publicity - characterized by language density, are skilfully-stylized in order to reach heterogeneous audience. In other words, the investigation has estimated and explained some contextual miscellany, in which ads function in unpredictable ways in order to influence readers of different socio-cultural domains.

\section{Literature review}

\subsection{Advertising and varieties of text}

Advertising has uncommon behavior towards text creation when compared to other domains of textual activations. This is because of the sensitization intention that the message is meant to achieve. As Cook (1992), particularly, argues that many people are not interested in reading ads. This is a raison d'être for constructing appalling frameworks for viewers' consumption. The mission that an ad is designed to serve mitigates its demonstration in the multifaceted forms (Sells \& Gonzalez 2003). Countless times, scholars (Brierley 1995; Forceville 1996) mention that the primary role that advertising plays in a social system is to persuade the public. The communication is a deliberate act of a professional to influence or perhaps, dictate to consumers the manner that individuals should conduct themselves. The feelings, intentions and perspectives of consumers on issues are "purchased" through the ad's message. Those personal features must be abandoned in order to espouse the instructions of the ads (Lakoff 1982). Rank (1988: 10) recognizes that target by classifying the advertising recipe of persuasion into the following steps: attracting the consumer's attention, building the product's confidence for the consumer, stimulating the consumer's desire, stressing the urgent need of the product to the consumer and seeking the consumer's positive response. The incitement of an advertising expert to construct variegated patterns of text, Dalamu (2018d) elucidates, is to achieve those principles. 
It is interesting to acknowledge that characterization of advertising texts has witnessed a sustainable growth since the linguistic pioneering effort of Leech (1966), much relevant today, being a canon of the linguistic analysis of advertising. Williamson (1978) contributes immensely to semiotics in advertising, describing hidden myths. However, studies in advertising continue to spread across linguistics' fields in order to reveal the contents. Of utmost importance is Vasiloaia's (2009) study on linguistic means of ads. Vasiloaia locates the merits of mnemonic devices of rhyme, rhythm, alliteration and assonance to guarantee that the audience will appropriately recall the message. Roberts (2013) examines graphology and lexical items in ads from a stylistic perspective. The inclusion of figurative expressions and simple dictions are additional contents in the work of Roberts. Vaičenonienè (2006), in the comparability of English and Lithuania advertising texts, observes that the advertising industry manipulates linguistic devices to achieve persuasion. The exploration shows lexico-grammatical devices, syntactic features, register, and rhetoric as properties of ads in those societies in their similarity and dissimilarity scopes. Slogan (Skorupa \& Dubovičienè 2015), culture (Kannan \& Tyagi 2013), generalization of stylistic features (Linghong 2006) and semantic implications (Emodi 2011) also penetrate the research of advertising textual fabrications. As the description of the advertising literature persistently proceeds to meet the degree of ads' ubiquity, scholars (Geis 1982; Geiszinger 2011) have categorized the language of ad into weasel lexemes, coinages, comparative and superlative adjectives, $y$-adjectives, compound words, imperative clauses and disjunctive linguistic organs. One might categorically-state that in spite of variations of text's dexterous workmanship, the significance of context avails as well as prevails, being a further justification for this study.

\subsubsection{Context in advertising}

The matter of context, unarguably, is language specific. The variability is a result of distinct beliefs associated with different socio-cultural milieu (Fiske 1989; Willis 1990; Grossberg et al. 1993; Brierley 1995; Van Dijk 2010). The term “context” was coined by Malinowski in 1923 to explain the relationships that occur between language utilization and a particular milieu. To Malinowski, the socio-cultural domain of a people determines the manner, in which individuals deploy the organic devices of their language (Butler 1985: 4-5). Context, as a fundamental terminology, permeates text in order to appreciate the semantic treasures of people's communication in real life and in the sense of its deployment (Halliday 1978; Ervin-Tripp 1994; Graber 2001). In a correlating point of view, Dash (2008: 21) describes context, as an embodiment and tremendous importance of meaning disseminations of actual texts. Dash (2008: 22-28) identifies local, sentential, topical and global domains, in which context operates. Therefore, advertising cannot properly function without sensitivity to the environment of the product. Context is important to text; text is important to advertising (De Voe 1956; Kövecses 
2005; Brzozowska \& Chłopicki 2015). It seems that the preferred option for advertising is to strictly adhere to context in order to be more meaningful and captivating. The culture of the target audience, in all ramifications, in Fiske's (1987) thought, must be sacrosanct to advertising production because consumers are interlocked with their cultural values (Barker \& Beezer 1992; Machin 2014). Be it branding, pictorial organization or textual manipulation, the social situation becomes a force to reckon with. Consumers, without doubts, place high premium on their cultural property.

Advertising takes the opportunity to connect the people (of a particular culture) with the product. The propagation of cultural treasures bridges the existing gulf between the product and the consumers (Morley 1992). Recipients experience such context in advertising from time immemorial. Hall et al. (1980) realize such inevitability to gloss that hardly can ads be produced without giving a preference for context. Sometimes, the context that a particular ad captures exceeds a single language community, but the communication rather spans several others (Maleej 2001). The practitioner signals a message that establishes the product in ways that make sense. That information conveys meaning potential to the public in their socio-cultural spheres, achieving mutual understanding. The ad prepares the product pictorially and textually, following a general communicative act, to meet urgent needs of recipients (Dalamu 2019c). The message tends to penetrate the consumers' worldview of consumption and tethers readers within that purview (Whiteman 1997; Gordon 2014). Curtaining the earlier opinion of Rank (1988), Hesselgrave (1995) suggests that advertising constructive contextualization must be tripartite, that is, to focus the people targeted, to consider the advertised product and to campaign, as it were, the proficiency of the craft advertiser, which may sometimes lean towards interruption of linguistic rules. Gumperz (1982: 20-28) refers to this language user's behavior as "Contextualization cues." Given all these opinions, one could recapitulate that context is not optional; nonetheless, a concern for environment in advertising is rather mandatory. The constructive attitudes of advertisers to text influence the writer to consider these textual-cum-imagery stylists as intellectuals, as expounded below.

\subsubsection{Intellectualism as advertisers' leeway}

Advertising constructs are a vessel of many individuals. These individuals are, perhaps, neither members of the academic community nor people with intellectual pedigrees. However, these individuals engage in the operational parallelism of intellectualism. By intellectualism, one means a probable practice of expressing opinions on certain topics in motivating ways accessible and beneficial to the public. The practice has the strength to attract attention or incite people to certain realities of life. The concept of an intellectual is not restricted to the academic. As Issitt \& Jackson (2013: 3) rightly encapsulate, "an intellectual is anyone who is thinking critically and employing a perspective that is informed and supported by systematic analysis.” Tri-polar devices, Issitt \& Jackson 
(2013: 6-7) explain, describe an intellectual individual: ability to project careful thoughts, a potency to convey rational views, and the question of whether his/her arguments attract procedural order. In addition, an intellectual has been characterized as a dissenter, revealer of truth, thinker, media super star, knowledge gatekeeper and an expert. Issitt \& Jackson (2013) emphasize that whosoever is classified as an intellectual must communicate his/her ideas passionately clearly, for instance, to consumers.

Moreover, Gramsci generalises intellectualism to everyone, yet, condenses its extremity by restricting such intellectual functions to a class of people. Gramsci (1971: 9) articulates that "[...] all men are intellectual... but not all men have in society the function of intellectuals”. One cannot agree less with Gramsci simply because training, to a large extent, separates an individual as being intellectual from another. In other words, formal education further portrays a person as an intellectual personality. Those who belong to the cadre of "knowing", according to Benda (1969), are very few people, whose principles of justice and incorruptibility are known and valued by many people. Gramsci (1971) classifies intellectuals into two categories of traditional intellectuals and organic intellectuals. The former group points to teachers, clergies, and so on, while the latter class belongs to entrepreneurial and advertising gurus, whose interest is keen on how to expand their businesses. In Gramsci's (1971) point of view, every professional individual is an intellectual in contrast to the argument of Benda (1969). To Benda, a demonstration of intellectualism constitutes individuals, who have adequate knowledge on social, material and spiritual matters, and perhaps, living a Spartan life.

In my quest, advertising intellectualism falls into the taxonomic endeavor of Gramsci (1971). Intellectualism is a leeway for advertisers in order to expand and dominate existing markets, and also to possibly create new ones. In a perfect and penetrating account, Said (1994) exemplifies intellectualism into professionals, expatriates, amateurs, and marginals. Irrespective of their degree of expertise, to Said (1994), intellectuals are sometimes controversial. In all these perspectives, except Spartanism, advertisers utilize intellectualism as a hemisphere to stimulate persuasion (Howard \& Walton 1983; Scott 1985; Morgan \& Welton 1986; Hawthorn 1987; Toolan 1988; Dalamu 2018b).

\subsection{Theoretical weight}

This study applies a combination of the mood system and morphological processes to the multilingual-propagated advertising texts. On that ground, Daramola (2008: 357) suggests that dual concepts from different theoretical mappings can be employed for data analysis in order to derive appropriate semantic merits.

\subsubsection{Mood system}

Interpersonal communication functions between the interactants. There are distinctive factors, as Halliday (1994) remarks, which explain the mood system of English, 
that is, the grammatical transpose of Interpersonal Metafunction. These are rudimentarily-principal speech roles that lie behind communicative interactions. Halliday \& Matthiessen (2004) recognize the speech roles as giving (good \& services or information) and demanding (good \& services or information). In Halliday \& Matthiessen's (2004) insight, the speaker is either giving a piece of information to the listener or the communicator is demanding something from an individual. Halliday \& Matthiessen (2014) refer to giving as inviting to receive, and demanding as inviting to give. The speaker is not only doing something him-/herself but the individual is also requiring something of the listener (Dalamu 2019a). The grammatical structures of declarative, imperative, interrogative, and modulated interrogative, in Thompson's (2014) keenness, identify relevant systemic structures of the mood system. Invariably, these linguistic terms are translated into the speech functions labeled as offer, command, statement and question (Eggins 2004; Fontaine 2013). Bloor \& Bloor (2013) epitomize the components of the mood's grammatical structures as Subject, Finite, Predicator, Complement, and Adjunct (SFPCA).

\subsubsection{Morphological processes}

Scholars, for example, Sapir (1921), Dixon \& Aikhenvald (2002), and Post (2009), have evaluated the formation of a word in its complexity. In a harmonious sense, a word is appreciated as a psychological, phonological, and grammatical phenomenon. The analyst can further report a word as an ark of semantic worth, eventual, and ultimate in social realizations. Nevertheless, irrespective of the descriptions attached to a word, there are due processes for word formations. These are morphological processes that seem to reveal and differentiate the appearance of one word from another. Word formation processes, following Zapata (2000), underscore relationships, constituent parts, and the internal organization of words either in relation to lexical and grammatical morphemes or bound roots and affixes. Morphemes in their kinds are combined to form lexemes in substantial varieties. The formation processes, as Zapata (2007) exemplifies, can come through any of the following terminal processes: compounding (endocentric, exocentric, and coordinative), acronym (jargon and alphabetism), blending (abbreviation), borrowing (loanwords), and clipping. Jackson \& Ze Amvela (2000) elucidate that back-formation, coinage (invention), functional shift, morphological misanalysis and eponymy operate in the field of word formation (Yule 1985; Malmkjaer 2004; Diessel n.d.). Thus, publicists employ word formation processes such as blending and compounding to create texts of their choices in order to inspire readers to consumption of both the constructs and the advertised products (Dalamu 2018c). Conversely, and sometimes, advertising communication dissents certain linguistic rules to achieve persuasion. 


\section{Methodology}

\subsection{Participants}

Bonke, a 35 year-old lady, provided a support for the author in collecting some ads from the signposts in Oshodi, Mushin, and Ketu Toll Gate of Lagos State, Nigeria. The assistance of Bonke became necessary because of her knowledge of strategic parts of Lagos where advertisers erect their communications for readers' viewing. The major responsibility of Bonke in this matter was to drive the analyst to the stated communities above as the collection exercises were being executed. Apart from that, the analyst searched The Punch newspaper (another custodian of ads) for ads constructed with cohesive resources in complex forms. Out of the sizeable number of ads collected about 10 of them were ultimate to the study.

\subsection{Research design and measures}

The researcher adopted a sampling method as a procedure to stratify the 10 pieces of ads, serving as population to three different sub-groups. Only five ads, representing a stratum of the population, were chosen for analysis. As the stratification has assisted the researcher in chosen the five ads from the group; it has also influenced a concise decision on the analyzed ads. This procedure greatly reduced the unnecessary cost of the project as well as augmenting the speed and accuracy of the investigation.

There were two electronic facilities that assisted the analyst during the data collection regime. These are: a Samsung $W B 50 F^{\circ}$ camera and an $h p 2000^{\circ}$ laptop. The author used the camera to capture some ads from both signposts and The Punch newspaper from where the pictures were downloaded to the laptop. At that juncture, the researcher utilized Microsoft Picture Manager ${ }^{\circ}$ to regulate the downloaded materials to required sizes and shapes. Thereafter, the ads were transferred to the appropriate positions in this article.

\subsection{Procedures}

The analyst considered some factors before the choice of 10 pieces of ads, functioning as population. These are: the nature of cohesive resources; discourse pattern; lexemic organization; clarity; and meaning projection of the ads. The researcher paid $\$ 10$, 000.00 (\# is a symbol of the Nigerian currency) to Bonke, who drove the car around to support the data collection exercise. The token was meant for car maintenance, and feeding. The five ads cover political institution, oil and gas, and fast moving consumer goods. As the concern of the paper was basically the specimen, the texts were copied out from the advertising frames for investigation. The Halliday's mood system along with morphological resources acted as intervening textual processors, which permitted tables and graphs to compute the values and frequencies of the communicative 
constituents. The approach of the discussion segment follows the path of technical word formations, functions of the structures, and their social implications to the consumer world. It is nice to mention that the application of nesting (//) indicates the demarcation of the simple clause in line with the tradition of Systemic Functional Linguistics (SFL), while the symbol, “®” displays a word as being registered. In addition, the study adopts AD1-AD5 to depict the examined ads.

\subsection{Data presentation}

AD1-AD5, below, represent the available textual constructs in the investigated ads.

- AD1: //Next month is FEBUHARI//

- AD2: //It's time to refuel//; //Ramadan Kareem//

- AD3: //FELABRATION the legendary experience//; //THE DIFF IS CLEAR//

- $\quad$ AD4: //Time for royal celebration//; //Share a Coke with Wills, Kate//

- AD5: //I AM OBIdienyly ATIKUlating this 2019//

\subsection{Mood structures analysis}

Figure 1, below, indicates the application of Halliday's mood system to the texts of the explored ads.

AD1 \begin{tabular}{|l|l|l|}
\hline Next month & is & FEBUARI 2015 \\
\hline Subject & Finite & Compl \\
\hline Mood & Residue \\
\hline
\end{tabular}

\begin{tabular}{|l|l|l|l|l|} 
AD2a & It & 's & time & to refuel \\
\cline { 2 - 4 } Subject & Finite & Compl & Adjunct \\
\hline Mood & Residue & \\
\hline
\end{tabular}

\begin{tabular}{|l|l|l|l|}
\cline { 2 - 3 } AD3a & Felabration & & the legendary experience \\
\cline { 2 - 3 } & Subject & Finite & Complement \\
\hline Mood & Residue \\
\hline
\end{tabular}

\begin{tabular}{|c|c|c|c|}
\hline \multirow[t]{3}{*}{$\mathrm{AD} 3 \mathrm{~b}$} & The diff & is & clear \\
\hline & Subject & Finite & Compl \\
\hline & Mood & & Residue \\
\hline
\end{tabular}

\begin{tabular}{|l|l|l|} 
AD4a & Time & for a royal celebration \\
\cline { 2 - 3 } & Compl & Adjunct \\
\hline Residue \\
\hline
\end{tabular}

\begin{tabular}{|l|l|l|l|} 
AD4b & Share & a Coke & with Wills and Kate \\
\hline \multicolumn{2}{|l|}{ Predicator } & Complmt & Adjunct \\
\hline Residue \\
\hline
\end{tabular}

\begin{tabular}{l|l|l|l|l|l|} 
AD5 & AM & OBIdiently & ATIKULATING & this 2019 \\
\cline { 2 - 6 } & Subject & Finite & Modal Adjunct & Predicator & Adjunct \\
\hline Mood & Residue & \\
\hline
\end{tabular}

Figure 1. Textual analysis of ads through mood system 


\subsection{Word-formation analysis}

The introduction of morphological processes in Figure 2 is a means of demonstrating textual formations that the mood system is unable to analyze in AD 1, AD 3, and AD 5.

FEBUARI $\left\{\begin{array}{l}\text { FE }+ \text { BUHARI } \longrightarrow \text { February } \\ \text { Buhari }(\text { Hausa })=\text { Name of APC Presidential candidate }=\text { Love } \\ \text { Love Buhari }=\text { a deconctruction of February }\end{array}\right]$ February

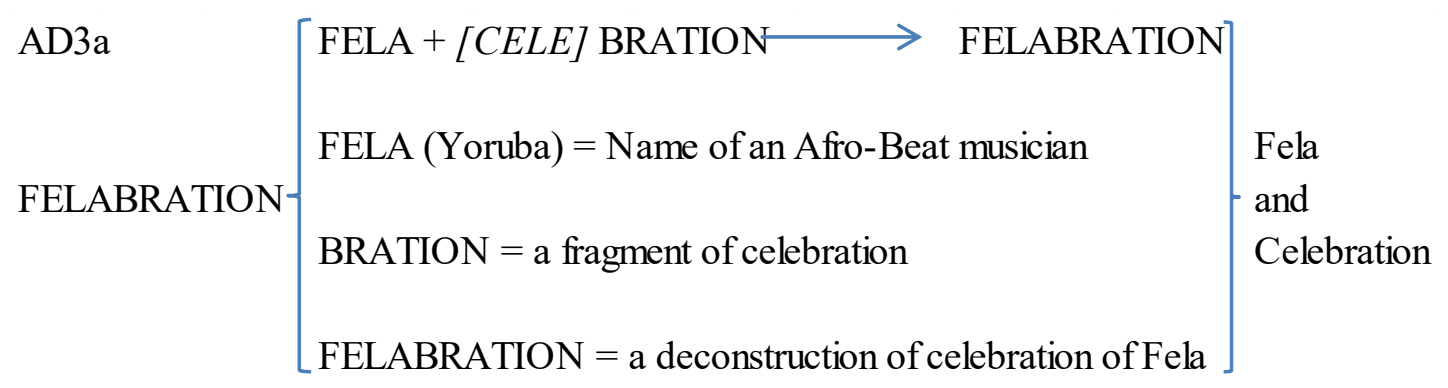

$\left.\begin{array}{l|l}\text { OD5 } & \begin{array}{l}\text { OBI }+ \text { [obe] diently } \longrightarrow \text { OBIdiently } \\ \text { OBI }(\text { Igbo })=\text { Name of a PDP Vice Presidential candidate } \\ \text { diently = a punctuated portion of obediently } \\ \text { OBIdiently = a deviant structure of obediently }\end{array}\end{array}\right] \begin{aligned} & \text { OBI } \\ & \text { and } \\ & \text { Obediently }\end{aligned}$

$\left.\begin{array}{l|l}\text { AD5 } & \begin{array}{l}\text { ATIKU }+[\text { articu }] \text { lating } \longrightarrow \text { ATIKUlating } \\ \text { ATIKU Hausa = Name of a PDP Presidential candidate } \\ \text { lating = a fragment of artuculating } \\ \text { ATIKUlating = a deviant construction of articulating }\end{array}\end{array}\right] \begin{aligned} & \text { ATIKU } \\ & \text { and } \\ & \text { Articulating }\end{aligned}$

Figure 2: Textual analysis of ads through morphological processes

\section{Results}

\subsection{Frequency patterns of the mood components}

Table 1 evaluates the recurrence of the contents of the mood system in the ads while Figure 3 calibrates the frequency of functions in table and pie chart. 
Table 1. The calibration of the mood system contents

\begin{tabular}{|l|l|l|l|l|l|l|}
\hline Mood System & Ad1 & Ad2 & Ad3 & Ad4 & Ad5 & Total \\
\hline Mood: Subject & 1 & 1 & 1 & 1 & 1 & 5 \\
\hline Mood: Finite & 1 & 1 & 1 & 1 & 1 & 5 \\
\hline Mood: Adjunct & 0 & 0 & 0 & 0 & 1 & 1 \\
\hline Residue: Predicator & 0 & 0 & 0 & 2 & 1 & 3 \\
\hline Residue: Complement & 1 & 1 & 2 & 1 & 0 & 5 \\
\hline Residue: Adjunct & 0 & 1 & 0 & 2 & 1 & 4 \\
\hline Minor Clause & 0 & 1 & 0 & 0 & 0 & 1 \\
\hline
\end{tabular}

Figure 3, as demonstrated below, represents the graphical translation of Table 1 above.

\begin{tabular}{|l|r|}
\hline Mood System & Recurrence \\
\hline Subject & 5 \\
\hline Finite & 5 \\
\hline Modal Adjunct & 1 \\
\hline Predicator & 3 \\
\hline Complement & 5 \\
\hline Adjunct & 4 \\
\hline Minor Clause & 1 \\
\hline
\end{tabular}

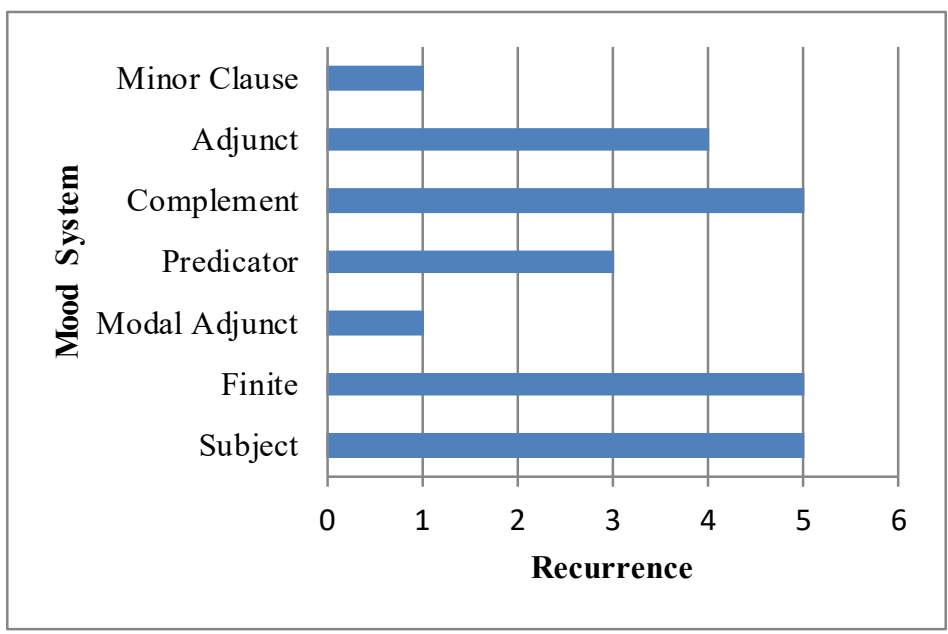

Figure 3. Mood system recurrence evaluation

With the frequency of five points, Figure 3 above exhibits Complement as the operational crux of the linguistic information. Next to this component are the concepts of Subject and Finite, functioning five times respectively. Nonetheless, the recurrent statuses of Complement and Subject point to the significance of the nominal group in the construction of texts.

Advertisers, having understood the weight of naming and concretizing events, deploy the nominal devices as persuasive facilities. There are also Adjunct and Predicator, which operate four times and two times respectively, with Minor Clause and Modal Adjunct, functioning just once. In sum, Figure 3 displays the advertisers' behaviors of utilizing the entire elements of grammatical structures to manipulate recipients, displaying nominal elements, stated earlier, as the greatest communicative tools of sensitization.

\subsection{Operational patterns of word-formation processes}

The compound formation of FE and BUHARI is an amazing idea not only because of the combinatory stimulation; it is also because of the fascination achieved which is quite 
educative. The blend of FE and BUHARI has yielded an imperative clause of FE-BUARI, an illustration of LOVE BUHARI, as demonstrated in Figure 2 to readers. This appeal commands readers not as voters, but as being in affection with BUHARI, a presidential candidate. Invariably, one could remark that if voters love someone contesting for a position such as the presidential office, courtesy seems to demand that individuals should vote for such contestant of choice. The strategy of the ad is to dodge the usual voting or campaigning slogan to the craft of something novel, revealed in this advertising framework as love, in the textual world. The textual style = Yoruba + Hausa + English.

FELABRATION is a construct associated with the morphology of blending. FELA as a word is joined to the punctuated content of BRATION. The production of FELABRATION is a contextual facility that points to the same functional protocol. FELA, in the Yorùbá cultural sphere, means relax to enjoy something. Celebration, an English lexeme, refers to a social gathering for fun and entertainment. The choice of combining FELA plus CELEBRATION to form FELABRATION is an excitement of a great communicative substance. The formation appears as a sacrament of persuasion, inviting readers to the event campaigned for. The textual style $=$ Yoruba + English .

\section{Discussion}

The explanations of the analysis will follow two directions: (i) manipulation and obstruction of texts, and (ii) the contextual implications of texts (Leech 1966; Myers 1994; Forceville 1996; Cook 2001; Dalamu 2017a).

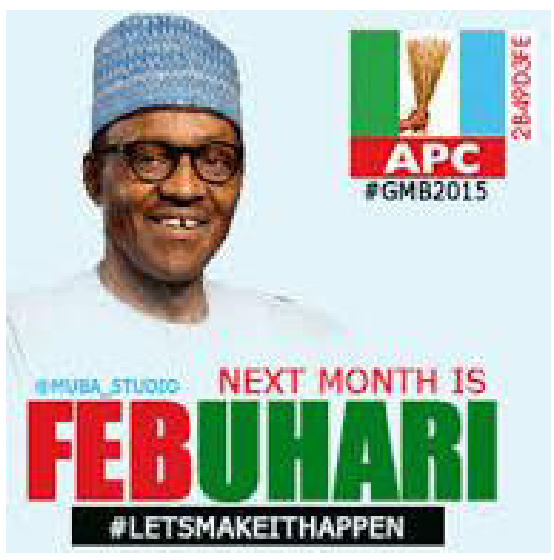

AD 1

AD 1 is a publication of a political party in Nigeria, known as, All Progressive Congress (APC). The political party published the communication in January 2015. The ad serves as a pointer to a voting event that ought to take place in the following month, February 2015. The political ad lays emphasis on the name of a political actor (Hall et al. 1980), Buhari, who is the presidential aspirant of APC. Two important elements are saliently publicized in the ad: Next month and FEBUHARI. However, these textual devices 
are two elements referring to a phenomenon at the same time. Next month refers to February 2015 and FEBUHARI summits to February. The ad demonstrates the significance of February 2015 to the APC political party. Observations reveal FEBUHARI, as a captivating facility of prominence. Apart from the coinage being capitalized, the twist is purposely fabricated to attract the public to the message. The manipulation has the capacity to influence the target audience to have profound interest in the ad.

Contextually, FEBUHARI is a compound word formation that functions in the domains of Yoruba, Hausa and English languages as mentioned earlier. The craft targets the users of the three languages. As exhibited earlier in Figure 2, the lexeme, FEBUHARI, accommodates two parts of $F E$ and BUHARI. FE, as a segment, is a Yorùbá word, meaning love. The second component, BUHARI, is Hausa, indicating a name of a person. To reiterate, the deformation of February (second month of a year) to FEBUHARI (love Buhari) creates a form of distraction (Ang 1991) to arrest readers' interest. Then, one could articulate that the unusual systematic and spellbound construct enjoins people to love Buhari in the coming February, being the month of election. The affinity in the request is not of any extraneous love than to vote for Buhari as the next Nigerian President in 2015. Love replaces vote to avoid monotony (Hopkins 2003), and perhaps, to create a new thing that is fanciful to the electorate. The creativity is laudable because of the relationship that the copywriter fabricates between February and Buhari. The multiplicity of the three spheres makes the ad an appealing piece that can influence millions of Nigerians to obey the order. Although FEBUHARI is a political lexeme, its sentential formation in English is domineering. That is: Love Buhari.

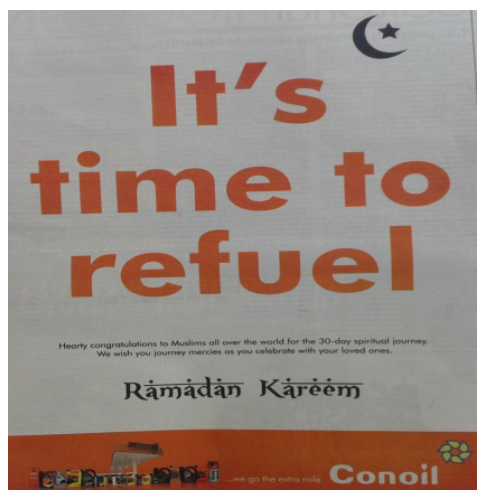

AD 2

The analyst has chosen two clauses from AD 2 because of their relevance to the communication's semantic implications. The first is a major clause whereas the second is minor. The application of the minor clause, Ramadan Kareem, serves as a salutation to the Muslim faithful. It's time to refuel sensitizes the Muslims to the next thing needed to be implemented after the fast, which has been on for about thirty days. The time in reference is the Eid-Mubarak, that is, the celebration that occurs immediately after the 
fasting regime. It is inciting to use the text refuel in the communication. Refuel falls into two separate contextual spheres. First, Refuel is metaphorical to Muslims as much as the construct is ambiguous to readers (Forceville 1996; Perez-Sobrino 2017). In that sense, the thirty day fasting seems a time that Muslim may not really enjoy a variety of foods. Now that the fasting period is ended, Conoil ${ }^{\circ}$ reminds Muslims to eat as much food as possible. Second, Conoil, the advertiser, is an oil and gas company that advises the target audience to refuel their vehicles during the festive season. One understands that so many people may either travel or visit their loved ones during the celebration, which attracts two-day public holidays, as part of the event. Given that awareness, the people must maintain their vehicles with Conoil products rather than another. The contextual ambiguity is associated with business (oil and gas) and Islam (religion), although the text communicates in English.

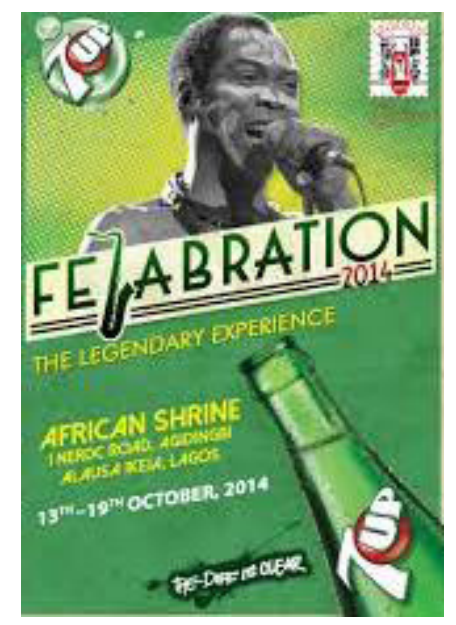

AD 3

There is a bold linguistic deformation in AD 3 to achieve the text FELABRATION. It is a "mishap" because FELABRATION is not a lexeme in any form of dictionary or day-to-day casual conversations except in the advertising world, as shown in AD 3. Besides, a few people who are Nigerians and sojourn in the musical orbit could understand the implications of the text. There is a little doubt that the text has a target audience. This indicates that every advertising construct is determined by its audience (Wang et al. 2002; Edegoh et al. 2013; Zipporah-Meru \& Mberia 2014; Sanusi \& Oloyede 2014). However, the pictures of Fela and Seven-Up enhance the message of the ad to unveil a relationship between the two elements. The "L" in Fela is intriguing for the linguistic letter is interchanged for saxophone as an identity of Fela. Such a proportional adjacency is as a result of what Fela represents in Nigeria, and by extension, the global world. As a global icon of music, Fela's prominence and dexterity are known in playing saxophone at its probable best. The publicist constructs the structural formation of FELABRATION from two languages of different socio-cultural domains - Yorùbá and English. FELA is adopted 
from Fela Anikulapo Kuti (Fela's full name); whereas -BRATION is lifted from a punctuated resource of celebration (i.e., ceremonial activity). This textual product is a form of blending in word formation processes. Thus, FELABRATION simulates or replicates (or perhaps is a mimicry of) an honorary solemnization of Fela's death and achievements in the music industry. The communication further refers to this promotion, as the legendary experience, aiming to showcase an unimaginable splendor, greatness, and excellence that Fela's musical genre represents in the entertainment industry. That extraordinary dogmatic notion is what people are invited to attend. Fela's doctrine, to Seven-Up, is distinguished and worth celebrating.

The application of DIFF further reveals that advertising is not bound by or in respect of certain perspectives on grammatical scales, in spite of attempts to establish principles for the practice (Read \& Loewenstein 1995; Hopkins 2003; Braun-Latour et al. 2004). One could state that the required rule in advertising is to violate a rule that could encumber advertising influential mission of charming recipients. Rather, the communication promulgates guidelines that exhibit its intriguing intention (Ogilvy 2013). Thus, DIFF is utilized instead of difference. DIFF is slang while difference is formal. The novel word manifests the uncommon pleasure experienced in consuming SevenUp, as consumers compare the product with another. AD 3 operates in the context of music genre of Afro-Beat and business of soft drink through the contentious engagement of Yorùbá and English.

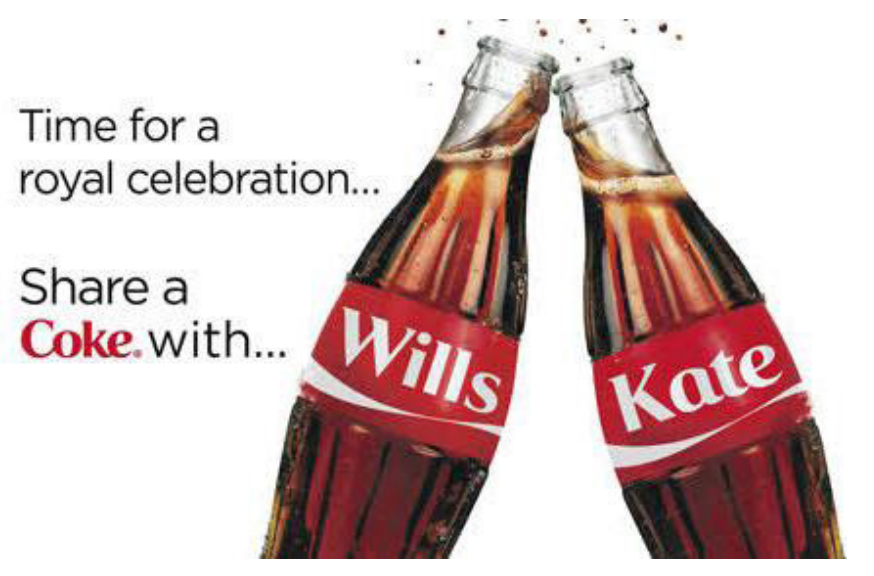

AD 4

AD 4 contains two clauses. The first one, Time for a royal celebration, is fragmented. The second, that is, Share a Coke with Wills and Kate, is imperative. The ad's commanding attribute stimulates the audience towards a non-optional consumption of CocaCola ${ }^{\oplus}$ A big and mental picture of a kingly emergence is created through Time for a royal celebration. That statement organizes a particular environment where a royal lineage is completely involved in patronizing the soft drink. The advertising plate projects an occasion for a special celebration, where kings, queens, princes, and princesses along 
with chiefs grace a setting. Perhaps, these kingly entities cannot rejoice alone without their friends and relatives. Meanwhile, Coke uses the occasion of a royal gathering as an opportunity to establish its presence as a drink of royal families. The association is a means of fraternizing with important people in society. In such situation, Coke is not only for the royal; Coke itself is a royal entity. To a considerable extent, from the purview of advertising, the consumption of Coke is a sign of royalty. The target audience, in the publicity expert's point of view, might be comfortable with the decoration of Coke in a majestic label. As a result of that, Coke becomes a reference point (Williamson 1978). So, Share a Coke with Wills and Kate pinpoints some participants who are royal themselves and celebrate with the royal. Drinking Coke, in this perspective, indicates a celebration among the royal personalities.

The cognitive deduction is that most people may love to consume a Coke bottle, where their names are christened. It is attested, from a general perspective that people love customized products (Piller \& Muller 2004; Syam et al. 2005; Mindtree n.d.). This is a sign of identity that accords people a long lasting respect. Having sublimated Wills, Kate on the bottle as labels, the emblems serve as royal crowns on the bearers of the names (Dellaert \& Stremersch 2005; Arora et al. 2008). Personalization of Coke bottles provides consumers an avenue to drink more bottles of Coke that contain their individual names. However, it may have a side effect on its consumption as well. This is because meeting individuals' specifications (Novaes et al. 2009; Spaulding \& Perry 2013) could be a huge task for the advertising experts to interchange everyone's name for Coke. Anyone whose name fails to appear on a Coke bottle may reject someone else's name and could refuse to drink Coke in an occasion. Even when the individual is thirsty, the person may opt for an alternative product. The texts featured as Time for a royal celebration and Share a Coke with Wills and Kate, along with the dual postures of Coke bottles, contextually, function in the domains of English communicative space, regal culture, and business environment.

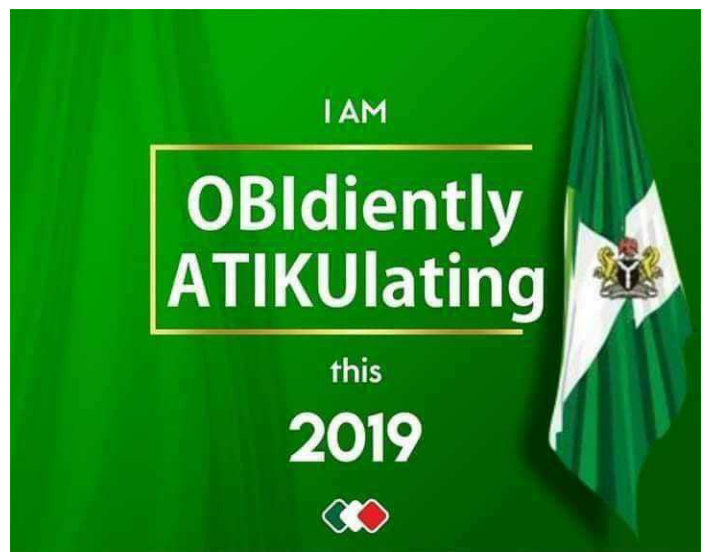

AD 5 
The systemic realization, in $\mathrm{AD} 5$, manifests a declarative clause in the form of a statement. A proclamation made by the Nigerian citizen, pledging a loyalty to the People Democratic Party (PDP) presidential and vice presidential candidates acknowledges individual's commitment. The linguistic element operates in the form of Mood and Residue. The Mood functions in its full-fledged forms of the Subject $(I)$, Finite $(A M)$, and Modal Adjunct (OBIdiently). The Residue of the clause reveals the Predicator (ATIKUlating) and Adjunct (this 2019). The content of the message is OBIdiently ATIKUlating, where obediently and articulating have been re-constructively-transformed to OBIdiently and ATIKUlating respectively. These textual facelifts are to match a political-rhetorical desire. On the one hand, $O B I$ is the name of the PDP presidential candidate employed to knock out obe-from obediently. As a result, one observes the generation of $O B I+$ diently to yield OBIdiently. That formation seems the reason for capitalizing OBI, as a mark of emphasis to indicate meaning potential to voters. On the other hand, ATIKU, being the name of the PDP presidential candidate, has been connected to articulating. The formation procedure is that the advertising practitioner utilizes capitalized ATIKU to replace articu-, mechanizing ATIKU + -lating to produce ATIKUlating - a verb in the gerund profile. Significantly, OBIdiently ATIKUlating, a deviant of obediently articulating, denotes the willingness of the individual citizen to surrender to the PDP authorities. Such compliance, one might suggest, is pronouncedly-eloquent, projecting an outright support for OBI-cum-ATIKU. On that basis, OBIdiently ATIKUlating specifies a sort of clarity of a well-spoken point, effectively tongued, fanatical to the instructions, declarations, and commands of the political party managers and candidates in the 2019 presidential election. As OBIdiently is a product of Igbo and English formations, so is ATIKUlating demonstrating Hausa and English expositions.

\section{Conclusion}

Advertising practitioners, as expressed in the investigation, are intellectuals without strict adherence to grammatical rule stipulations. This is because the kind of intellectualism practiced does not function within the context of basic or rigid principles as obtained, for instance, in the academic world. Text and context are twin-brothers in advertising (e.g., FELABRATION). That quality makes communication objects requisite entities, which provide relevant meanings in a particular environment (e.g., refuel). Because advertising does not seem to wilfully flourish as a rule-chained or rule-abiding phenomenon always; advertising communicators rely heavily on that advantage to construct messages within multiple contexts (e.g., FEBUHARI) in a single frame. This tendency can assist a product to convince so many audiences of varied socio-cultural backgrounds at once. Sometimes, linguists, and other analysts, might question the formation of novel constructs (e.g., OBIdiently; ATIKUlating) in spite of the poetic license exercised. One might comment that this study has established the English language to 
play an overbearing role in the formation processes, expressing its hegemonic status in the Nigerian communicative hemispheres. However, the creation of diversity in context has the strengths to augment language development in society. There is a need for government policy makers to encourage advertising experts to brace their efforts in constructing new lexemes by setting up a body, perhaps, of lexicographers, to be examining and collating novel words that will be part of language use. This effort can increase the compendium of the language word-stock in several interactive spheres. After all, language is dynamic, a fundamental force and particle, revolving around human activities.

\section{References}

Akinnaso, N. N. 2015. The politics of language planning in education in Nigeria. Word 41 (3): 337-367. Retrieved on 12 June 122018 from https://www.tandfonline.com/doi/abs/10. 1080/00437956.1990.11435827?src=recsys.

Alt, F., Evers, C. \& Schmidt, A. 2009. Pervasive computing group users' view on contextsensitive car advertisements. Pervasive Computing 9-16.

Ang, I. 1991. Desperately Seeking the Audience. London: Routledge.

Arora, N., Dreze, X., Ghose, A., Hess, J., Iyengar, R., Jing, B., Joshi, Y., Kumar, V., Lurie, N., Neslin, S., Sajeesh, S., Su, M., Syam, N., Thomas, J. \& Zhang J. 2008. Putting oneto-one marketing to work: Personalization, customization, and choice. Science and Business Media, Marketing Letters 19: 305-321.

Awobuluyi, O. 2010. Linguistics and Nation Building: The Prof. Emeritus Ayo Bamgbose Personality Lecture. Ibadan: DB Martoy Books.

Bakshy, E., Eckles, D. \& Yan, R. 2012. Social Influence in Social Advertising: Evidence from Field Experiments, 146-166. http://weigend.com/files/teaching/stanford/2014/bakshy13.pdf. Barker, M. \& Beezer, A. (eds.) 1992. Reading into Cultural Studies. London: Routledge. Benda, J. 1969. The Treason of the Intellectuals. New York: Norton.

Bloor, T. \& Bloor, M. 2013. The Functional Analysis of English. Abingdon: Oxon, Routledge. Bogart, L. 1995. Strategy in Advertising. Chicago: NTC Books.

Braun-Latour, K. A., Latour, M. S., Pickrell, J. E. \& Loftus, E. F. 2004. How and when advertising can influence memory for consumer experience. Journal of Advertising 33(4): 7-25. Brierley, S. The Advertising Handbook. London: Routledge.

Brzozowska, D. \& Chłopicki, W. (eds.) 2015. Culture's Software: Communication Styles. Newcastle upon Tyne: Cambridge Scholars.

Cook, G. 1992. The Discourse of Advertising. New York: Routledge.

Dalamu, T. O. 2017a. A functional approach to advertisement campaigns in AngloNigerian Pidgin. Studies in Linguistics 44: 155-185. 
Dalamu, T. O. 2017b. Maternal ideology in an $\mathrm{MTN}^{\oplus}$ advertisement: Analyzing socio-semiotic reality as a campaign for peace. Journal of Language and Education 3(4): 16-26. DOI: 10.17323/2411-7390-2017-3-4-16-26.

Dalamu, T. O. 2018a. Exploring advertising text in Nigeria within the framework of cohesive influence. Styles of Communication 10(1): 74-97.

Dalamu, T. O. 2018b. Euphemism: The commonplace of advertising culture. Acta Scientiarum. Language and Culture 40(2): 1-15.

Dalamu, T. O. 2018c. English language development in Nigerian society: A derivative of advertising communications. Complutense Journal of English Studies 26: 263-286.

Dalamu, T. O. 2018d. Advertising communication: Constructing meaning potential through disjunctive grammar. Anagramas Rumbos y Sentidos De La Communicación 17(33): 73-104.

Dalamu, T. O. 2019a. Halliday's mood system: A scorecard of literacy in the English grammar in an L2 situation. Revista de Estudos da Linguagem 27(1): 241-274.

Dalamu, T. O. 2019b. A Discourse Analysis of Language Choice in $M N^{\circledR}$ and Etisalat Advertisements in Nigeria. Beau Bassin: LAP Lambert Academic Publishing.

Dalamu, T. O. 2019c. Textual artifact of advertising: A thrust of Halliday's mood system resources. Revista Brasileira de Linguística Aplicada 19(3): 407-454.

Dalamu, T. O. 2020. Discoursing children characteristics of Zenith Bank ${ }^{\oplus}$, Nigeria, Advertising: An expression of clause as representation. Journal of Language and Linguistic Studies 16(1): 333-365.

Dash, N. 2008. Context and contextual word meaning. SKASE Journal of Theoretical Linguistics 5(2): 21-31.

De Pelsmacker, P., Geuens, M. \& Leuven, V. 2002. Media Context and Advertising Effectiveness: The Role of Context Appreciation and Context-Ad Similarity. http://citeseerx. ist.psu.edu/viewdoc/download?doi=10.1.1.198.6804\&rep=rep1\&type=pdf.

Dellaert, B. \& Stremersch, S. 2005. Marketing mass-customized products: Striking a balance between utility and complexity. Journal of Marketing Research XLII: 219-227.

De Voe, M. 1956. Effective Advertising Copy. New York: Macmillan.

Diessel, H. n.d. Morphological Processes. http://www.personal.uni-ena.de/ x4diho/INTRO_ Morphological_processes.pdf.

Dixon, R. \& Aikhenvald, A. 2002. Word: A typological framework. In: R. Dixon \& A. Aikhenvald, A. (eds.), Word: A Cross-Linguistic Typology, 1-4. Cambridge: Cambridge University Press.

Edegoh, L., Nwanolu, I. \& Ezeh, N. 2013. Audience assessment of the use of models in billboard advertising: A study of consumers of Amstel Malt in Onitsha, Nigeria. International Review of Social Sciences and Humanities 6(1): 217-227.

Emenanjo, N. E. (ed.) 1990. Multilingualism, Minority Languages and Language Policy. Agbor: Central Books Limited. 
Emodi, L. N. 2011. A semantic analysis of the language of advertising. African Research Review: An International Multidisciplinary Journal, Ethiopia 5(4): 316-326.

Ervin-Tripp, S. 1994. Context in language. In: D. Slobin, J. Gerhardt, A. Kyratzis \& J. Guo (eds.), Social Interactions, Social Context, and Language. Hillsdale, NJ: Lawrence Erlbaum Associates.

Fiske, J. 1987. Television Culture. London: Methuen.

Fiske, J. 1989. Understanding Popular Culture. London: Unwin Hyman.

Fontaine, L. 2013. Analyzing English Grammar: A Systemic Functional Introduction. Cambridge: Cambridge University Press.

Forceville, C. 1996. Pictorial Metaphor in Advertising. New York: Routledge.

Gieszinger, S. 2001. The History of Advertising Language. Frankfurt: Peter Lang.

Piller, F. \& Muller, M. 2004. A new marketing approach to mass customization. International Journal Computer Integrated Manufacturing 17(7): 583-593.

Goddard, A. 2011. The Language of Advertising. London: Routledge.

Gordon, C. 2014. Contextualization cues. Key Concepts in Intercultural Dialogue 57. http://centerforinterculturaldialogue.org.

Graber, P. 2001. Context in Text: A Systemic Functional Analysis of the Parable of the Sower [Unpublished doctoral dissertation]. Emory University, Atlanta, GA. http://www.isfla. org/Systemics/Print/Theses/PhilipgraberDiss.pdf.

Gramsci, A. 1971. The Prison Notebook. New York: International Publishers.

Greenwald, A. \& Leavitt, C. 1984. Audience involvement in advertising: Four levels. Journal of Consumer Research I(1): 581-592.

Grossberg, R., Nelson, C. \& Treichler, P. (ed.) 1993. Cultural Studies. London: Routledge.

Hall, S., Hobson, D., Lowe, A. \& Willis, P. (eds.) 1980. Culture, Media, Language. London: Unwin Hyman.

Halliday, M. A. K. 1978. Language as Social Semiotic. London: Edward Arnold.

Halliday, M. A. K. \& Matthiessen, M. I. M. C. 2004. An Introduction to Functional Grammar. London: Hodder Arnold.

Halliday, M. A. K . \& Matthiessen, M. I. M. C. 2014. Halliday's Introduction to Functional Grammar. Abingdon, Oxon: Routledge.

Harris, R. \& Seldon, A. 1962. Advertising and the Public. London: Andre Deutsch.

Hawthorn, J. (ed.) 1987. Propaganda, Persuasion and Polemic. London: Edward Arnold.

Hesselgrave, D. 1995. Contextualization that is authentic and relevant. International Journal of Frontier Missions 12(3): 115-119.

Hopkins, C. 2003. Scientific Advertising. Sedona: Carl Galletti.

Howard, D. \& Walton, P. (eds.) 1983. Language, Image, Media. New York: St. Martin's.

Igboanusi, H. (ed.) 2001. Language Attitude and Language Conflict in West Africa. Ibadan: Enicrownfit Publishers. 
Issitt, J. \& Jackson, D. 2013. What Does it Mean to Be a Public Intellectual? https://www.heacademy.ac.uk/system/files/resources/12_march_presentation.pdf.

Jackson, H. \& Ze Amvela, E. 2000. Words, Meaning and Vocabulary: An Introduction to Modern English Lexicology. London: Continuum.

Kannan, K. \& Tyagi, S. 2013. Use of language in advertisements. English for Specific Purposes World 37(3): 2013. http://www.esp-world.info.

Kaplan, R. B., Baldauf A. Jr. \& Richard, B. 2007. Language Planning and Policy in Africa, vol. 2: Algeria, Côte d'Ivoire, Nigeria and Tunisia. Bristol: Channel View Publications Ltd/Multilingual Matters.

Kövecses, Z. 2005. Metaphor in Culture: Universality and Variation. Cambridge, Mass.: Cambridge University.

Lakoff, R. 1982. Persuasive discourse and ordinary conversation, with examples from advertising. In: D. Tannen (ed.), Analyzing Discourse: Text and Talk, 239-311. Georgetown: Georgetown University Press.

Linghong, Z. 2006. The linguistic features of English advertising. CELEA Journal 29: 1. http://www.celea.org.cn/teic/65/65-71.pdf.

Maalej, Z. 2001. Processing pictorial metaphor in advertising: A cross-cultural perspective. Academic Research 1: 19-42.

Machin, D. (ed.) 2014. Visual Communication. Berlin: Mouton de Gruyter.

Malaviya, P. 2007. The Moderating Influence of Advertising Context on Ad Repetition Effects. http://www18.georgetown.edu/data/people/pm289/publication-40242.pdf.

Malmkjaer, K. (ed.) 2004. The Linguistics Encyclopedia. London: Routledge.

Mindtree n.d. Winning in the Age of Personalization Global Survey Compares Consumer Expectations Against Industry Initiatives. http://www.mindtree.com/personalization/global/pdf/mindtree-survey-report-personalization-global.pdf.

Morgan, J. \& Welton, P. 1986. See What I Mean: An Introduction to Visual Communication. London: Edward Arnold.

Morley, D. 1992. Television Audiences and Cultural Studies. London: Routledge.

Myers, G. 1994. Words in Ads. London: Arnold.

Ogilvy, D. 2013. The Confessions of an Advertising Man. Harpenden, Herts: Southbank Publishing.

Ojelade, K. \& Ezenandu, P. E. (eds.) 2010. Language and National Development: A Book in Honor of Prince Adebisi Adedotin Bepo. Abeokuta: Palletspat Konsepts.

Ozo-mekuri, N. (ed.) 2010. Language, Policy, Planning \& Management in Nigeria: A Festschrift for Ben O. Elugbe. Port Harcourt: M \& J Grand Orbit Communications Ltd. Perez-Sobrino, P. 2017. Multimodal Metaphor and Metonymy in Advertising. Amsterdam/ Philadelphia: John Benjamins.

Post, M. 2009. The Phonology and Grammar of Galo 'Words'. http://researchonline.jcu.edu. au/17852/1/Post_Phonology\%26Grammar.pdf. 
Rank, H. 1988. Persuasion Analysis: A Companion to Composition. Park Forest, IL: Counter-Propaganda Press.

Read, D. \& Loewenstein, G. 1995. Diversification bias: Explaining the discrepancy in variety seeking between combined and separated choices. Journal of Experimental Psychology: Applied I(1): 34-49.

Robert, S. 2013. Language of Advertising: A Study of Nigeria's Nation Newspaper and Newswatch Magazine. http://dx.doi.org/10.5539/jel.v2n3p61.

Said, E. W. 1994. Representations of the Intellectual: The 1993 Reith Lectures. New York: Vintage Books.

Sanusi, B. \& Oloyede, D. 2014. Audience perception of the role of advertising on product positioning and brand loyalty in the Nigerian GSM market. Kuwait Chapter of Arabian Journal of Business and Management 3: 6. http://www.arabianjbmr.com/pdfs/KD_ VOL_3_6/24.pdf.

Sapir, E. 1921. Language. New York: Harcourt, Brace.

Scott, W. D. 1985. The Theory of Advertising: A Simple Exposition of the Principles of Psychology in Their Relation to Successful Advertising. New York: Garland Publishing.

Sells, P. \& Gonzalez, S. 2003. The Language of Advertising. http://www.york.ac.uk/language/ staff/academic-research/peter-sells.

Skorupa, P. \& Dubovičienè, T. 2015. Linguistic characteristics of commercial and social advertising slogans. COACTIVITY: Philology, Educology 23(2): 108-118.

Spaulding, E. \& Perry, C. 2013. Making it Personal: Rulesfor Success in Product Customization. http://www.bain.com/Images/BAIN_BRIEF_Making_it_personal.pdf.

Syam, N., Ruan, R. \& Hess, J. 2005. Informs customized products: A competitive analysis. Marketing Science 24(4): 569-584.

Thompson, G. 2014. Introducing Functional Grammar. Abingdon, Oxon: Routledge.

Toolan, M. 1988. The language of press advertising. In: M. Ghadessy (ed.), The Register of Written English: Situational Factors and Linguistic Factors, 52-64. London: Francis Pinter.

Vaičenonienè, J. 2006. The language of advertising: Analysis of English and Lithuanian advertising texts. Studies about languages 9: 43-55.

Van Dijk, T. A. 2010. Discourse and Context: A Sociocognitive Approach. Melbourne: Cambridge University Press.

Vasiloaia, M. 2009. Linguistic features of the language of advertising. Economy, Transdisciplinarity, Cognition 1. http://www.ugb.ro/etc/etc2009no1/s0804\%20\%282\%29.pdf. Accessed 13 June 2016.

Wang, C., Zhang, P., Choi, R. \& Díeredita, M. 2002. Understanding consumers' attitude toward advertising. Eighth Americas Conference on Information Systems. HumanComputer Interaction Studies in MIS, 1143-1148.

Whiteman, L. 1997. Contextualization: The Theory, the Gap, the Challenge. http://www.internationalbulletin.org/issues/1997-@1/1997-@1-@०2-whiteman.pdf. 
Williamson, J. 1978. Decoding Advertising: Ideology and Meaning in Advertising. New York: Marion Boyars.

Willis, P. 1990. Common Culture: Symbolic Work at Play in the Everyday Cultures of the Young. Milton Keyes: Open University Press.

Yule, G. 1985. The Study of Language. Cambridge: Cambridge University Press.

Zapata, B. A. 2000. Handbook of General and Applied Linguistics. Trebajo de Ascenso sin publicar - erida, Venezuela: Escuela de Idiomas Modernos, Universidad de Los Andes.

Zapata, B. A. 2007. Types of Word and Word Formation Processes in English. http://webdelprofesor.ula.ve/humanidades/azapata/materias/english_4/unit_1_types_of_words_and_ word_formation_processes.pdf.

Zipporah-Meru, M. \& Mberia, H. 2014. The effects of celebrity endorsement in advertisements. International Journal of Academic Research in Economics and Management Sciences 3(5): 178-118.

$* * *$

Taofeek O. Dalamu earned a PhD from the University of Lagos, Nigeria, under a methodical supervision of Prof. Adeyemi Daramola, with specialization in Systemic Functional Linguistics, Discourse Analysis, and Digital Humanities in relation, mostly, to advertising communications. Currently, Dr. Dalamu is a member of International Systemic Functional Linguistics Association, and teaches English courses at Anchor University, Lagos, Nigeria. This scholar has a variety of 32 publications in reputable international journals across the globe. See: www.hq.ssrn.com/taofeekdalamu/papers, www.researchgate. net.cdn/taofeekdalamu, www.academia.com/taofeekdalamuuniversityoflagos. 